\title{
CLIMATE-INDUCED MIGRATION AND INSTABILITY: \\ THE ROLE OF CITY GOVERNMENTS
}

Ambika Chawla | 2017

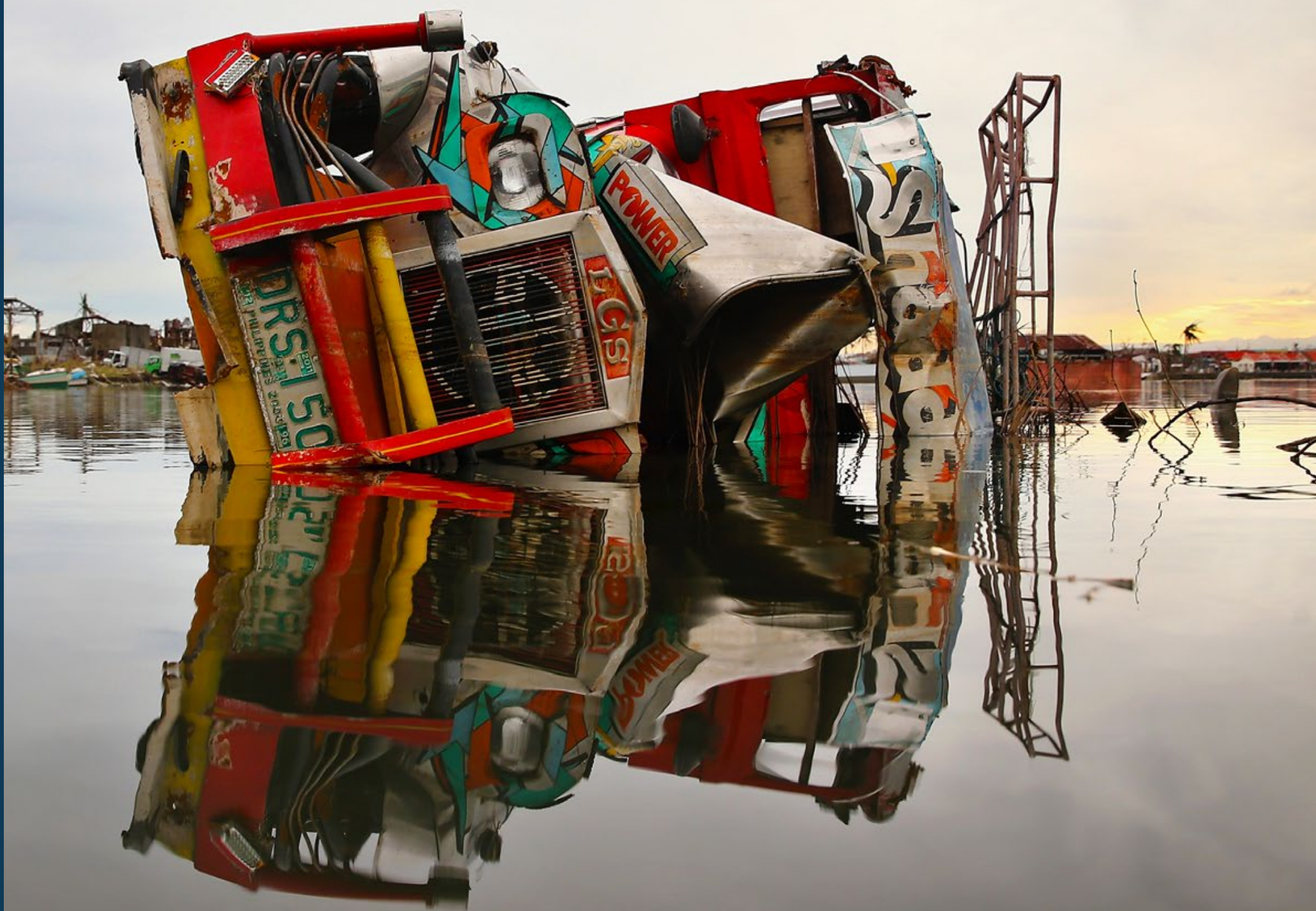

An OEF Research Discussion Paper

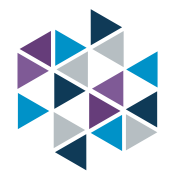

OEF Research 


\section{CLIMATE-INDUCED MIGRATION AND INSTABILITY: THE ROLE OF CITY GOVERNMENTS}

Ambika Chawla | 2017

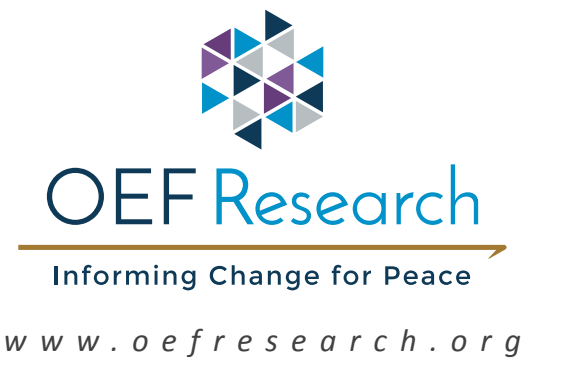

OEF Research is a program of

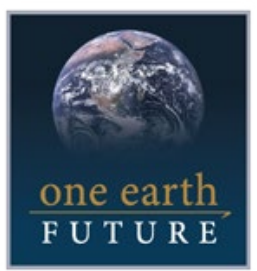

Peace Through Governance

oneearthfuture.org 


\section{EXECUTIVE SUMMARY}

- Rural-to-urban migration due to slow or sudden-onset climate change is expected to continue in the coming decades, with Northwest Africa, India and Bangladesh, the Andean region, and China being "hotspots." Many climate migrants are moving to "fragile cities" characterized by poor governance and limited capacity to provide their residents with adequate infrastructure and social services. Influxes of climate migrants are likely to exacerbate these problems, and migrants may experience exclusion from government services when they arrive in cities in low- and middle-income countries.

- As the world becomes more urban, the focus within the discourse on governance, peace, and security is increasingly shifting from the fragile state to the fragile city. Poor governance and an inability to deliver services in fragile cities result in city dwellers being exposed to violence and instability. There will also be a rise in the number of fragile cities due to urban population growth in fragile states.

- The existing research on provision of social services and integration into governance systems suggests that in general, exclusion from the procedures or benefits of such systems can contribute to intergroup tensions, crime, and political instability. In fragile cities, city-level governance can represent a specific point of failure that prevents specific groups from accessing public goods. Climate migrants are a significant stressor for these already fragile systems, and may contribute to the crime, instability, and conflict.

- These dynamics mean that city governments can play an important role in peace and security. In contrast to national and international actors, local government authorities are in close proximity to their residents and can design policies and initiatives rooted in local realities. Strategies to improve public infrastructure, legal systems, and service delivery and include local groups in city governance can reduce the vulnerabilities of climate migrants and associated security risks.

- In order to tackle local-level challenges, city institutions need to build partnerships with international actors. They should strengthen ties with UN agencies, multinational companies, regional and international banks, think tanks, and international humanitarian and peacebuilding organizations. The building of bridges with global research programs can fill in the gaps in knowledge on urban trends, governance, migration, and security. Enhanced knowledge can help city leaders design better policies and programs to address the climatemigration-security nexus. Stronger partnerships with humanitarian organizations can help effectively deliver humanitarian assistance to climate-displaced people. 


\section{TABLE OF CONTENTS}

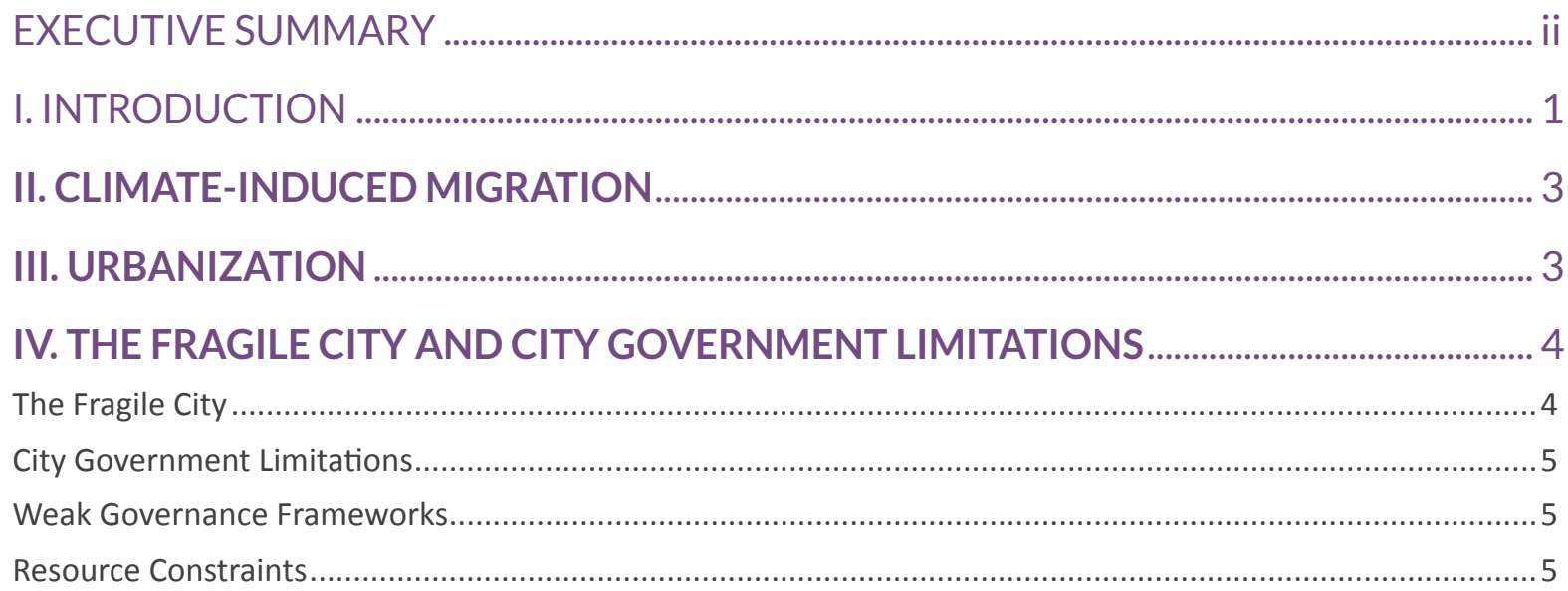

V. CHALLENGES FACED BY MIGRANTS: LIMITED ACCESS TO SOCIAL SERVICES............7

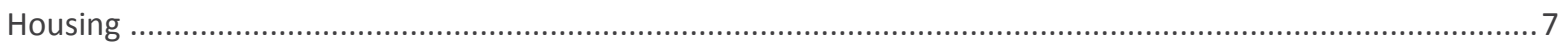

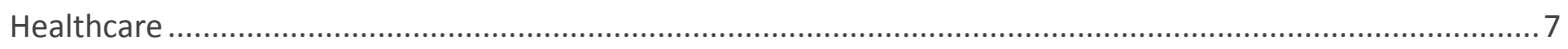

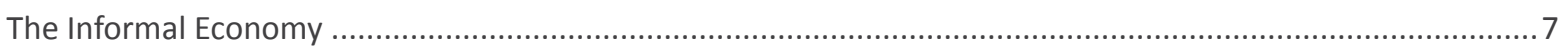

VI. CITIES, WEAK GOVERNANCE, AND CLIMTATE-INDUCED MIGRATION:

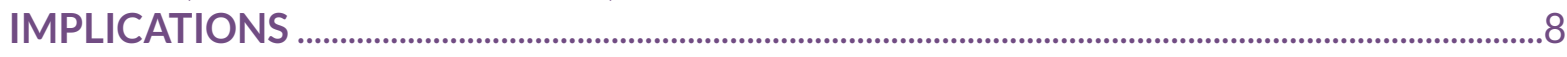

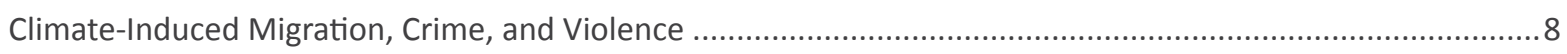

Climate-Induced Migration, Instability, and Political Violence ...................................................................

VII. CITY GOVERNMENT SOLUTIONS TO ADDRESS THE CHALLENGES ASSOCIATED

WITH CLIMATE-INDUCED MIGRATION .............................................................................................11

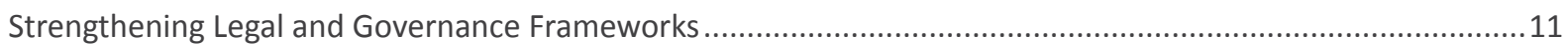

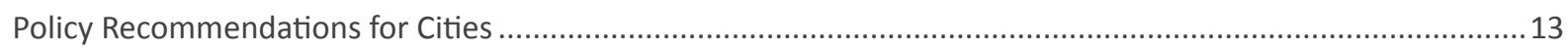

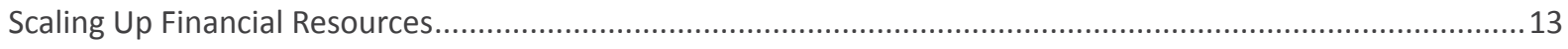

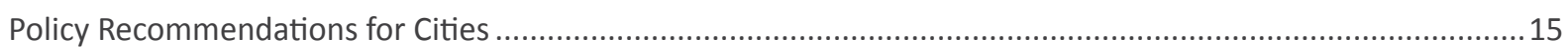

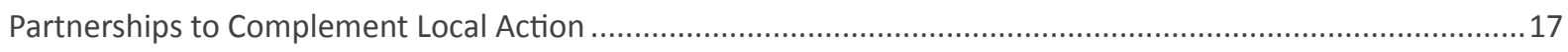

Policy Recommendations for Cities ................................................................................................... 17

VIII. CONCLUSION: CITIES AS THE OVERLOOKED GOVERNANCE VARIABLE..................20

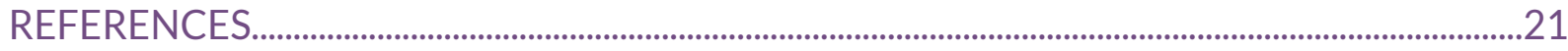




\section{INTRODUCTION}

In November of 2013, Super Typhoon Haiyan-one of the strongest tropical storms on record-hit the Philippines, causing tremendous damage to the country's infrastructure, destroying thousands of homes, and forcing hundreds of thousands of people to take shelter in emergency evacuation centers. More than 6,000 people were killed ${ }^{1}$ and 4 million people were displaced. ${ }^{2}$ Thousands of typhoon survivors migrated from rural areas to the country's capital city of Manila. ${ }^{3}$

This is not an isolated case. As climate change increases the number and impact of severe weather events, many countries are forced to cope with the impacts of natural disasters. Natural disaster is a major driver of internal displacement, representing a larger cause of displacement than armed conflict and violence at the global level. ${ }^{4}$ In addition, climate change is likely to lead to an increase in migration and displacement for other reasons, as sloweronset challenges such as changes in water availability and rising sea levels change the human habitability of different regions. Currently, most migration is characterized by urbanization: a movement of peoples from rural to urban areas. ${ }^{5}$ This trend of urbanization will likely be a particular feature of climate-related migration in the developing world, due to the general trends towards urbanization in general and the specific climate-related vulnerabilities found in developing countries and in particular those in Africa and south and east Asia. ${ }^{6}$

Trends in urbanization and climate change are changing the landscape of human settlements around the world, which will affect living conditions in all parts of the world. Many cities in the developing world have limited governance mechanisms and are financially constrained, conditions which significantly hinder their capacities to deal with the complex urban problems which confront them. Policymakers at all levels will therefore need to focus attention on the important role of cities and dedicate their resources to supporting city governments in solving the pressing urbanization challenges in their territories. To be specific, they will need to support "bottom-up" policies and strategies that build the resilience of cities to address the manifold urbanization-climate-induced migration challenges within their jurisdictions.

Homes beside railroad tracks in Dhaka, Bangladesh. Photo: Asian Development Bank

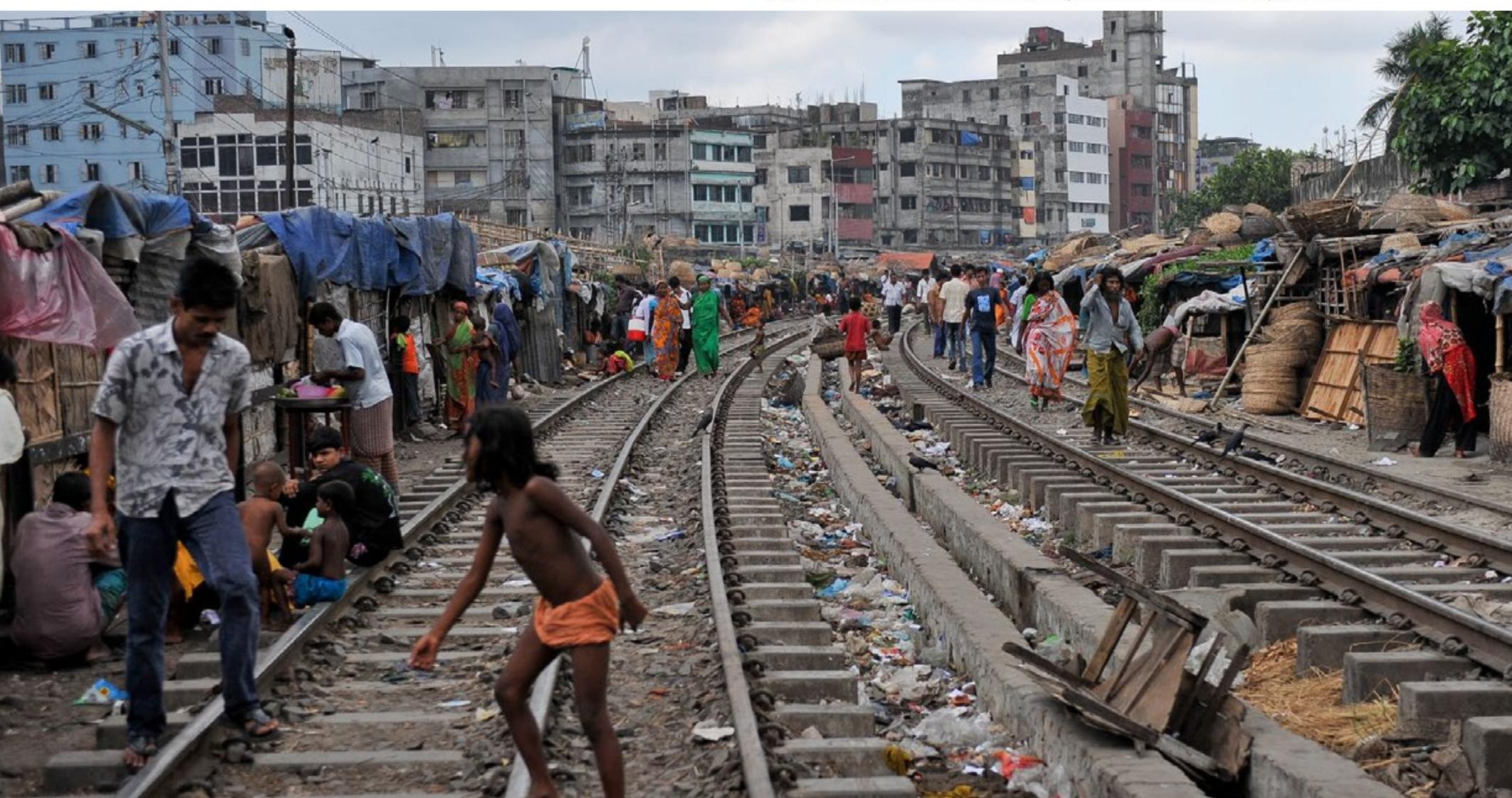


As climate change puts structural pressures on people internationally, current trends suggest that the result will be an increase in urban migration. Today, an estimated $60 \%$ of the world's displaced people live in urban contexts, most of them in cities of conflict-affected countries that are already struggling to maintain stability. ${ }^{7}$ This means that in countries already struggling with service delivery and integrating rural-to-urban migrants into the economy, climate change is likely to lead to increasing pressures on city-level systems. This, in turn, suggests that city-level governance may be a critical factor affecting whether this migration results in increasing disruption to social services and stability or whether it can be converted into healthy growth of these cities. In regions strongly affected by climate change, the question of the quality of governance at the city level as much as at the level of the state may be critical to whether the region is able to effectively navigate the challenges posed by climate change.

The aim of this discussion paper is twofold: First, the paper will examine how climate-induced migration is linked to urban fragility, crime, and violence at the city level. Currently, increasing numbers of climate migrants are moving to "fragile cities" 8 in the developing world. The fragile city is characterized by poor governance and limited capacity to provide residents with basic services and infrastructure. Due to these institutional constraints, many climate migrants are likely to experience exclusion from social services and employment opportunities. These conditions of exclusion may increase the risk of crime and violence at the city level.

Second, this paper introduces city governments as crucial actors and potentially innovative problem-solvers to address the peace and security challenges associated with climate migration. In contrast to national and international actors who are far removed from local residents, city governments are in close proximity to their communities and can design initiatives that are rooted in local realities. The key to addressing the security challenges associated with climate migration will be to ensure that these migrants have access to vital urban services in their respective cities. However, most cities in low- and middle-income countries struggle to provide even basic services to their residents. City governments will need to strengthen their ties with UN agencies, international donor agencies, and multinational corporations, as these institutions can channel much-needed resources and investments toward local government services and infrastructure. City officials will also need to create inclusive governance frameworks to ensure that climate migrants have a voice in city decision-making processes, especially given that migrant communities are often made invisible in urban contexts due to their weak legal status and their limited opportunities for participating in city governance.

This report is aimed at city policymakers and local stakeholder groups, primarily mayors, municipal government officials, and civil society leaders tasked with addressing the many local-level challenges within their territories. The hope is that the report can provide these city decision-makers with a greater understanding of the security risks of climate-induced migration, along with ideas on how they can develop effective policies for peace and stability.

This paper is based on a review of the literature on climate-induced migration and displacement, the fragile city and its limitations to accommodating the needs of climate migrants, the links between climate migration and crime and violence at the city level, and city-wide policies to tackle pressing migration-related security challenges. The paper draws primarily upon academic literature, reports from the International Organization for Migration and UN-Habitat, and news articles. 


\section{CLIMATE-INDUCED MIGRATION}

\author{
CS What we are now seeing are more \\ and more people that are forced to flee \\ because of lack of water, because of lack \\ of food, because of extreme poverty and \\ many of these situations are enhanced by \\ climate change. 29 \\ -António Guterres, United Nations High \\ Commissioner for Refugees ${ }^{11}$
}

There is increasing evidence that one result of ongoing climate change will be an increase in the displacement of peoples internationally. As climate change leads to changes in water availability in some areas and rising sea levels in others, as well as increased risk of natural disasters, the regions best suited for human life and economic activity are going to change. ${ }^{9}$ In some cases, entire states or regions that are currently inhabited may be rendered uninhabitable: for

example, climate scientists predict that the small island nation-state of Tuvalu could be completely submerged within the next 50 years if sea levels continue to rise. ${ }^{10}$ The result will likely be shifts in human habitation and displacement in many parts of the world. This was recognized in the first assessment report of the Intergovernmental Panel on Climate Change, which said that "the gravest effects of climate change may be those on human migration as millions are displaced by shoreline erosion, coastal flooding and severe drought."12

In addition to the permanent changes in habitability, one result of climate change is an increase in severe weather events. These are already a major contributor to migration and displacement. The Migration Policy Institute estimated in 2015 that natural disasters led to the displacement of 184.6 million people between 2008 and $2014 .{ }^{13}$ In 2013, displacement due to natural disasters was estimated to be about three times the number of people displaced by conflict and violence. ${ }^{14}$ As climate change continues to contribute to severe weather events, the long-term scale of displacement is predicted to increase. ${ }^{15}$

\section{Climate Change Impacts Which Lead to Displacement}

From the Brookings Institution report on climate change and migration ${ }^{16}$

- Increased droughts and slow-onset disasters such as desertification, leading to water scarcity. This in turn reduces food security and economic activity based on agriculture.

- Existential threats posed by rising sea levels to low-lying areas including coastal areas and small island states.

- More frequent and more severe weather, including increases in threats posed by hurricanes and typhoons, flooding, tornados, and severe storms.

\section{URBANIZATION}

While climate change is expected to trigger the movement of peoples both within national borders (internal migrants) and across them (international migrants), most climate-induced migration currently takes place in the form of rural-urban migration within nation states, with this trend expected to continue in the coming decades. ${ }^{17}$ Adverse climate effects can drive rural-to-urban migration in many ways. Sea-level rise along coastal areas will lead to an increase in the number of people moving to urban centers. Dhaka, in Bangladesh, receives nearly 500,000 people 
rapidly - for example, in the wake of extreme climate events-or more incrementally, often due to the weakening of governance structures. ${ }^{30}$ The future will also see a rise in the number of fragile cities due to urban population growth in conflict-affected states. By 2050, over $50 \%$ of the population in conflict states will be living in cities.

The inability of these cities to provide their residents with basic services, infrastructure, and security will lead to conditions that create additional instability and even violent crime. ${ }^{31}$ For example, according to UN-Habitat as reported by Savage and Muggah, more than $80 \%$ of global urban growth over the next few decades is likely to take place in poor squatter settlements. ${ }^{32}$ Those who live in slum settlements are generally poor, with limited opportunities for formal employment, and are correspondingly more likely to engage in crime or violent crime for economic reasons..$^{33}$ In addition, slum neighborhoods are often beyond the control of municipal security forces. ${ }^{34}$ The divide in economic opportunities across social groups in a given urban area is another driver of fragility, as this social segregation leads to a breakdown in formal urban governance, leading to the likelihood of an increase in criminal violence at the city level.

The developing fragility of some cities exposes a general threat to stability in the twenty-first century. As urbanization increases, city and regional governments are increasingly put under pressure to effectively deliver security, social services, and economic activity to the complex and growing city. Some cities are weathering this challenge with smart policies and sustained engagement with their communities, but others are struggling. Against this backdrop, the threat of climate-induced migration operates as an additional destabilizing factor: as climate stressors increase, urbanization may increase. In addition, climate disasters such as sudden natural disasters or severe drought can cause a sudden surge in urban migrants who may lack housing opportunities, training for urban jobs, and financial resources. These climate-related pressures will put stressors on city governance systems to address the problems that are caused.

\section{City Government Limitations}

This section provides a more detailed engagement with the role that city governments play in accommodating the needs of climate migrants. Ways in which city governments in low- and middle-income countries are constrained in their capacities to adequately accommodate the needs of climate migrants who

Weak governance structures make it difficult for city officials to ensure that climate migrants are engaged in urban decision-making, and more importantly, that their concerns are integrated into local development plans.

arrive in their territories are outlined. Due to these institutional and resource constraints, climate migrants are likely to face many obstacles for accessing the services that a city can offer; primarily housing and healthcare services. In addition, migrants are likely to be marginalized from formal employment opportunities. As a result, the risk of crime and violence may increase in these cities.

Weak governance structures make it difficult for city officials to ensure that climate migrants are engaged in urban decision-making, and more importantly that their concerns are integrated into local development plans. ${ }^{35}$ The majority of these cities are resource-constrained, with limited funding available to provide the necessary infrastructure to deal with population growth; i.e., transport, power, water supplies, and sanitation. These financial constraints also make it difficult for local governments to ensure that climate migrants have access to vital social services. Information and data on internal migration are limited in terms of availability and accuracy, therefore constraining the ability of municipal decision-makers to develop adequate policies to address the challenges that may arise with increased climate-induced migration.

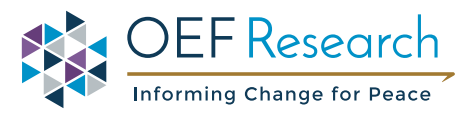




\section{Infrastructure Constraints}

City governments in low- and middle-income countries are limited in their capacities to provide basic waste management/sanitation, water, transport, and energy services to their residents. These city governments are often financially strapped, with limited resources to invest in the maintenance or improvements of public infrastructure. Globally, almost 700 million urban residents lack access to adequate sanitation infrastructure. ${ }^{36}$ In Africa, only half of the large cities have a sewerage network in place. ${ }^{37}$ For example, in Dar es Salaam, a city of 4 million, as few as 5-10\% of city dwellers are connected to a sewer system. ${ }^{38}$ In addition, many city dwellers in developing countries lack access to clean water. It is estimated that $27 \%$ of urban residents in the developing world do not have piped water in their houses. ${ }^{39}$ Those who suffer the most from these water- and sanitation-related challenges are the urban poor, as water and sanitation services are primarily channeled to middle and upper class neighborhoods. ${ }^{40}$ The result can be serious impacts on health among city dwellers: lack of access to clean water is the cause of approximately $10 \%$ of all disease internationally. ${ }^{41}$ Access to affordable energy services is another pressing challenge for many city dwellers. It is estimated that $40 \%$ of people living in Sub-Saharan African cities lack access to electricity. ${ }^{42}$ In Addis Ababa in Ethiopia, almost $60 \%$ of city households suffer from multidimensional energy poverty - lack of access to clean cooking fuel and electricity or electrical appliances. ${ }^{43}$

\section{Weak Governance Frameworks}

Fragile cities suffer from an imbalance of political power, most notably a lack of participation on the part of local stakeholder groups. ${ }^{44}$ Overall, cities in low- and middle-income countries have weak legal frameworks for citizen participation in place, with disadvantaged populations, such as migrant groups, being marginalized from city decision-making processes. Moreover, the unclear conditions of residence of new migrants often interfere with their ability to vote and thus engage in the political life of the city. ${ }^{45}$ Another common challenge is that the activities of individual departments within a given municipal government are often fragmented, with poor interaction and coordination between various urban sectors such as housing, health, water, sanitation, and energy. Finally, cities in developing countries are characterized by incoherence between national and local-level policies, with a lack of coordination between these two levels often leading to ineffective approaches to migration policy. ${ }^{46}$

\section{Resource Constraints}

In addition to the mentioned governance-related challenges, cities in low- and middle-income countries are mostly resource-constrained. They have limited revenue sources of their own (i.e., from property taxes, fees and charges, business taxes, sales taxes, and land use taxes), ${ }^{47}$ with a large portion of their financial resources coming from shared taxes with national governments as well as intergovernmental transfers. Their financial situations are often characterized by budget deficits, debts, and the inability to repay loans. ${ }^{48}$ Decentralization tends to put additional pressure on municipal finances as cities are increasingly expected to implement national policies at the local level. ${ }^{49}$ Another challenge is that as cities grow, financing for basic infrastructure and social services is unable to keep up with the needed pace and meet demand for these new services, placing additional strains on already limited financial resources. ${ }^{50}$ It is estimated that $\$ 200$ billion in investments in infrastructure and services made annually until 2035 would be required for cities in the developing world to meet these gaps. ${ }^{51}$ City government expenditure as a percentage of GDP is particularly low in most African countries, where, on average, city government revenue represents only $7 \%$ of total public revenue. ${ }^{52}$ Finally, city governments often lack accountability and transparency when it comes to sharing information about municipal budgets and financial planning. ${ }^{53}$

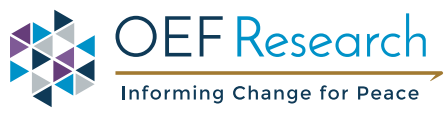




\section{CHALLENGES FACED BY MIGRANTS: LIMITED ACCESS TO SOCIAL SERVICES}

\section{Housing}

Due to institutional and resource constraints, newcomers face many obstacles to accessing the services that a city can offer, primarily housing and healthcare services. Access to adequate, affordable housing and shelter is a challenge for many urban migrants. The World Bank estimates that developing countries should prepare to house an additional 2.7 billion people by 2050 , primarily due to rural-to-urban migration. ${ }^{54}$ Urban migrants in low- and middleincome countries often lack official registration papers, which prevents them from accessing municipal housing services. ${ }^{55}$ In addition, new arrivals often cannot afford decent-quality housing. As a result, the majority of urban migrants live in informal settlements (i.e., slum settlements) or in overcrowded temporary shelters, ${ }^{56}$ and make up a disproportionate amount of the urban poor in in informal settlements. ${ }^{57}$

\section{Healthcare}

Migrant populations have a greater risk of having poor health. Poor migrants are often employed in risky jobs, exposing them to hazardous chemicals, among other threats. ${ }^{58}$ They are also more susceptible to infectious diseases as they generally must live in crowded and unhygienic conditions..$^{59}$ Migrant workers in cities have a high rate of HIV/AIDS, as high-risk sexual behavior and high levels of migration in urban areas generally coincide.$^{60}$ While migrants face greater health risks, they often find that they are excluded from municipal healthcare systems. They face geographic barriers in accessibility of healthcare clinics as they tend to live in informal settlements located on the peripheries of urban centers. Moreover, health services are often too costly for new migrants. Finally, they rarely possess any kind of official documentation in their new places of work, which makes it difficult for them to access municipal healthcare clinics. In China, for example, millions of urban migrants do not possess proper official documentation and thus do not have access to healthcare services. ${ }^{61}$

\section{The Informal Economy}

Migrants tend to be on the margins of the formal economy, taking part in the "informal economy" of the city, which is generally characterized by unsafe working conditions, low wages, irregular incomes, and long working hours. Recent estimates are that over $50 \%$ of workers in West Africa and $48 \%$ of workers in South Asia are part of 
the informal sector. ${ }^{62}$ In the city of Dhaka, which attracts thousands of climate migrants every year, approximately $75 \%$ of the urban population is engaged in informal employment activities. ${ }^{63}$ Migrants who take part in the informal economy have limited legal or social protection, as they are rarely covered by labor laws. Employment without official contracts means that labor codes and regulations are easily violated and that workers are susceptible to early dismissal. In the Vietnamese cities of Hanoi and Ho Chi Minh City, approximately $60 \%$ of migrants are employed without any formal contract. ${ }^{64}$ Women migrants are particularly vulnerable to exclusion from formal employment as they are over-represented in the lowest-paid segments, and on average earn less than male migrants. ${ }^{65}$

\section{SEWA: The Self-Employed Women's Association, India}

The Self-Employed Women's Association (SEWA) was founded in 1972 by civil rights leader Dr. Ela Bhatt in Ahmedabad, India. SEWA supports women working in the informal sector in India. The organization is run by women workers who earn a living through their own labor or small businesses. SEWA has helped women gain access to markets, social services, and banking facilities that allow them to save and borrow

capital to start their own enterprises. In addition, SEWA assisted with passing India's Unorganised Sector Workers' Social Security Act in $2008^{66}$. As a result of SEWA initiatives, a large number of female informal workers in India have achieved self-reliance. As of 2014, almost 2 million women workers were

\section{CITIES, WEAK GOVERNANCE, AND CLIMATE-INDUCED MIGRATION: IMPLICATIONS}

\section{Climate-Induced Migration, Crime, and Violence}

Climate migration is taking place within the already weak governance systems of fragile cities. These cities struggle with providing social services and incorporating their citizens into local governance; climate migrants load an additional burden onto this system. This section discusses some of the impacts.

One major issue is social exclusion: climate migrants are moving into systems which frequently struggle with inclusion of extant groups. People who are socially excluded are generally also poor, primarily because they are denied opportunities for formal employment and access to vital services. In addition, there is evidence that there are links between poverty, criminal behavior, and violence. According to the International Labour Organization, chronic unemployment, which results in poverty, is associated with an increase in criminal behavior. ${ }^{67}$ Burton, ${ }^{68}$ Nathan, ${ }^{69}$ and Sandbrook ${ }^{70}$ concur that poverty as defined by a person having their basic needs be unmet, in particular food and water, often leads to violence. A study conducted by the World Bank found that on average, the countries that experienced major violence had a poverty rate significantly higher than countries with no violence. ${ }^{71} \mathrm{Goodhand}$ argues that poverty contributes to growing grievances among people, with the potential for open conflict to occur when these underlying grievances are triggered by external shocks. ${ }^{72}$

Climate migrants are likely to move to informal slum settlements. There is evidence that residents of informal slum settlements are at a greater risk of criminal violence. Slums are often located on the peripheries of urban security systems where police are less able to regulate, for example, guns and other weapons. ${ }^{73}$ In addition, slum dwellers generally lack access to formal work opportunities and basic services, conditions which can foster criminal 
violence. ${ }^{74}$ According to Buvinic and Morrison ${ }^{75}$ as well as Glaeser and Sacerdote, ${ }^{76}$ the combination of competition for resources along with weak security systems in slum settlements often leads to criminal activity. In the city of Nairobi, for example, in the last 20 years, violent crimes such as armed robbery, murder, physical assault, and sexual assault have steadily increased, with most of this violence taking place in the city's largest slums of Mathare and Kibera. ${ }^{77}$ Politically motivated violence is not uncommon in Kibera as this slum is home to many different ethnic and political groups, ${ }^{78}$ notably, for example, the violence that erupted during the 2007 presidential elections in Kenya. ${ }^{79}$ Gender-based violence is particularly high in Kibera; in fact, almost $85 \%$ of women there have experienced either sexual or domestic violence. ${ }^{80}$

\section{The Safer Nairobi Initiative}

The Safer Nairobi Initiative supports community-based strategies for preventing crime and violence in Nairobi81. The initiative was founded in 2004 as part of Nairobi's Urban Safety strategy. The main objective of the initiative is to "improve urban safety and security in a sustainable way by addressing root causes of crime through a multi-faceted approach." The main activities for the Safer Nairobi Initiative include:

- Strengthening the institutional capacity of the city of Nairobi to better enforce law and violenceprevention initiatives. In particular, the city encourages participatory, local-level approaches to preventing violence in Nairobi.

- Working with urban planners to design an urban environment that is secure and safe.

- Encouraging the active participation of local community groups in urban safety and crimeprevention initiatives.

Research finds that crime and violence are likely to accompany deprivation from basic urban services and infrastructure. ${ }^{82}$ Poor transportation infrastructure can create situational opportunities for violence, making it easier for perpetrators to commit crimes without being seen by the police. ${ }^{83}$ An examination of Mexican squatter settlements during the 1980s found that squatters in slum settlements were especially prone to random violence when they lacked basic urban services. ${ }^{84}$ Recent research in Jamaica found that violent crimes occurred most often in inner-city communities without basic utilities. ${ }^{85}$ According to a recent report by ActionAid International, ${ }^{86}$ when women and girls in cities lack access to basic urban services such as transport, water, and sanitation, they are left vulnerable and exposed, leaving them susceptible to becoming victims of crime and violence. ${ }^{87}$ The study illustrates the example of Mombasa in Kenya, where women and girls who live near and around the Mwakirunge dumpsites lack access to basic services, particularly water and electricity, and as a result experience high levels of violence. ${ }^{88}$

Collectively, therefore, there is strong evidence that poverty and exclusion from economic and social goods can contribute to an increase in violence. Rapid urbanization creates these conditions as migrants overload the physical and social systems for inclusion and access to public goods. This trend is already occurring, as Muggah noted in his conception of fragile cities. As climate stressors create a new wave of climate migrants in fragile countries internationally, there is likely to be an increase in cities adversely affected by this migration. 


\section{Climate-Induced Migration, Instability, and Political Violence}

One concern posed by climate analysts is that climate change may contribute to political instability and potentially political violence. Much of the current thinking on climate, conflict, and security builds on work emphasizing the ways in which environmental degradation and scarcity can lead to conflict. According to Renner, "history provides numerous examples of how states and nations were destabilized by environmental collapse leading to famine, migration, and rebellion." ${ }^{\prime 19}$ Ross argued that resource degredation increased the risk of civil war through several pathways. ${ }^{90}$ Homer-Dixon claims that environmental scarcities can exacerbate conditions of poverty, which in combination with weak governance structures can lead to outbreaks of violent conflict in the developing world. ${ }^{91}$ Diamond, in his book Collapse: How Societies Choose to Fail or Succeed, argues that "problems of deforestation, water shortage, and soil degradation in the Third World foster wars there." ${ }^{\prime 2}$

According to the Intergovernmental Panel on Climate Change, climate change will lead to environmental degradation. ${ }^{93} \mathrm{~A}$ review of the literature finds that there are five main ways that the effects of climate change can lead to conflict: 1) resource scarcity can lead to unemployment and to the loss of local livelihoods, thereby increasing the potential for conflict;; ${ }^{94}{ }^{95}$ 2) weak governance structures and reduced state income may hinder the delivery of public services and infrastructure and thus give rise to political instability; ${ }^{96}$ 3) human displacement and migration resulting from climate change can contribute to conflict within states and between states; ${ }^{97} 4$ ) migration can increase the potential for ethnic tensions in receiving areas, ${ }^{98}$ and 5) migration to receiving areas can lead to increased competition and conflict over scarce resources. ${ }^{99}$

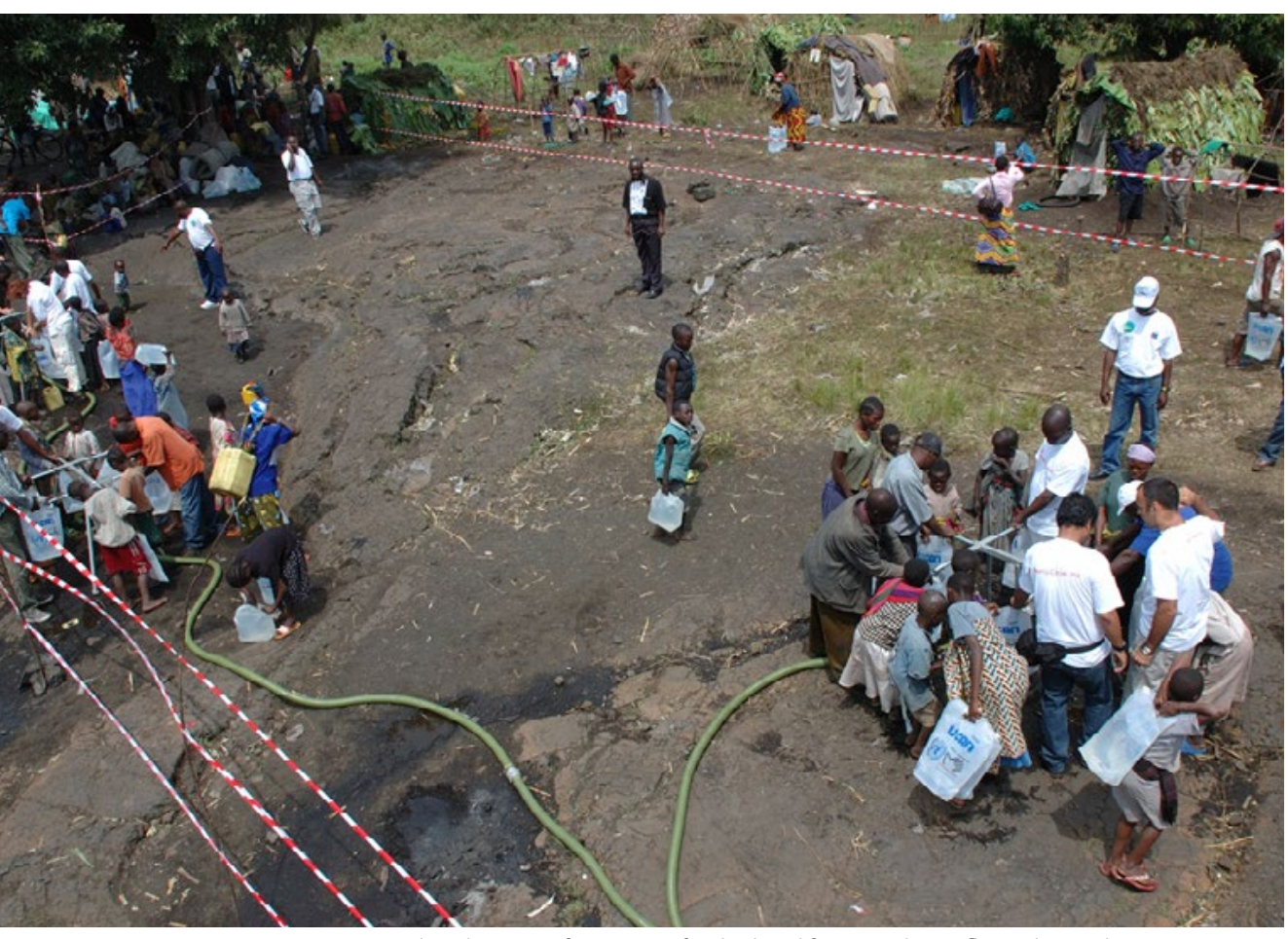

Water points in South Sudan at a refugee camp for displaced from nearby conflicts. Photo:Julien Harneis
Researchers who have directly examined the climate migrationconflict link have concluded that there is a connection. Reuveny examined 38 cases of environmental migration occurring since the 1930s and found that in half of them, there was some kind of armed conflict, with migration likely to intensify intrastate and interstate disputes. ${ }^{100} \mathrm{He}$ found that ethnic tensions and competition over scarce resources were key drivers of armed conflict. Gleditsch ${ }^{101}$ as well as Buhaug and Theisen ${ }^{102}$ contend that climate-related natural disasters and sea-level rise will lead to the loss of local livelihoods and economic productivity, resulting in migration. They argue that migration, in confluence with weak governance structures at the local and state levels, is likely to lead to instability by promoting increased opportunities for organizing violence. Werz and Conley ${ }^{103}$ highlight four regions in the world-northwest Africa, India and Bangladesh, the Andean region, and China-as "hotspots" for potential conflicts associated with climate-induced migration. On the other hand, Raleigh, Jordan, and Salehyan 
argue that climate-induced migration is typically internal and short-term and thus the potential for conflict is minimal. ${ }^{104}$

The majority of the challenges posed by migration will take place at the level of the city. Because the majority of climate-induced migration is to urban areas, urban areas become the context in which these competitions for resources, jobs, and political engagement play out. The most common government system that urban migrants will interact with will be the city government: when analysts such as Homer-Dixon point out that governance weaknesses can contribute to conflict, they are talking about failures of city governance as much as state. On the other hand, if city-level governments are able to effectively manage the challenges posed by climate migrants, then these challenges may be overcome.

\section{CITY GOVERNMENT SOLUTIONS TO ADDRESS THE CHALLENGES ASSOCIATED WITH CLIMATE-INDUCED MIGRATION}

Given their close proximity to local community groups, city governments are uniquely positioned to introduce innovative approaches to addressing the security challenges associated with climate-induced migration. First, cities will need to strengthen their legal and governance frameworks. Ensuring that climate migrants have a voice in city governance can help city officials and migrant groups work hand in hand to craft local action plans to improve the delivery of infrastructure and social services for climate migrants. Municipalities can also introduce laws to ensure that climate migrants are protected in the workplace. Next, cities need considerable financial resources to provide displaced people with humanitarian assistance and to ensure that they have access to public services, security, and basic infrastructure. Financial resources can come from private companies, international development banks, UN agencies, and international humanitarian and peacebuilding organizations. Given the limited institutional capacities of cities to effectively deal with climate migration-related security challenges, city government authorities will need to build partnerships with international donor agencies, international humanitarian organizations, and local and national governments in the developed world. There is also a need for city governments to build bridges with think tanks and their global research programs at the international level in order to gain a better understanding of the dynamics between urban fragility, climate-induced migration, and security at the city level.

\section{Strengthening Legal and Governance Frameworks}

\section{When local governments adopt initiatives for inclusive governance, they are likely to foster conditions conducive to peace and stability.}

Research shows that ensuring that civil society groups have a voice in city governance may prevent violence and conflict. Cortright et al. note that governance systems which are based on participation, accountability, and inclusivity contribute to more peaceful and stable societies. ${ }^{105}$ Davenport argues that when mechanisms are in place

to give citizens a voice in decision-making in political life, they are less likely to use violence as a means to make their voices heard. ${ }^{106}$ Consensus-based systems, where all stakeholder groups have a voice, can also lower the risk of armed conflict, particularly in multiethnic communities. ${ }^{107}$ Thus, when local governments adopt initiatives for inclusive governance, they are likely to foster conditions conducive to peace and stability.

Ensuring that marginalized groups, such as migrants, are included in decision-making processes is the cornerstone of democratic governance at the city level. In the 2015 World Migration Report, contributions from Cécile Riallant of the Joint Migration and Development Initiative argue that the most effective urban interventions to address migration- 
related challenges are those where migrant communities are consulted and where they have developed strong ties to their local governments. ${ }^{108}$

One approach to engaging climate migrants in city governance is to include them in the design of joint local action plans. City officials and climate migrants can work together to craft local action plans to improve the delivery of infrastructure and social services for climate migrants, as well as the delivery of aid from humanitarian organizations. Funding for these local action programs can come from international development organizations, UN agencies, local and national governments in the developed world, and the European Union.

\section{The City of Honiara Adopts Conflict-Sensitive Measures ${ }^{109}$}

Honiara is the capital city of the Solomon Islands and has a population of 80,000 . The city is growing aggressively, with an annual urban growth rate of $4 \%$ per year. Since the 1990 s, the city of Honiara has been a center for ethnic violence. In early 2000 an armed group representing displaced Malaitians violently took control of the city briefly. As a result, the city council of Honiara adopted a number of conflict prevention strategies and measures to promote ethnic inclusiveness:

- The city established a Council of Chiefs as a forum for city leaders and residents to address conflicts due to ethnic tensions.

- The city council and the Ministry of Home Affairs created the Honiara City Council Institutional Capacity Building Project, a five-year partnership aimed at improving local institutional and servicedelivery capacity. The goal is to foster conditions for peace and stability through the improved delivery of services in Honiara.

- A Local Peace Monitoring Council was established.

- Measures to promote transparency, openness, and inclusion in city governance were undertaken.

- The city established a number of programs to address youth unemployment.

In addition, city government authorities can strengthen legal frameworks and introduce new laws to promote the inclusion of climate migrants in the formal employment sector. Given the links between unemployment, crime, and violence, city leaders can introduce legislative incentives and policies to increase employment opportunities, particularly for young people. Cities can introduce robust laws to protect informal workers. Durban City, South Africa, and Lima, Peru, have introduced some innovative labor laws, providing a model for other local governments to follow. In 2014, the city of Lima passed an ordinance which recognizes street vendors as official workers with legal rights. ${ }^{110}$ In addition, the ordinance led to the establishment of a commission which encourages dialogue between street vendors and city officials. ${ }^{111}$ In 2001, Durban City (eThekwini) in South Africa introduced its Informal Economy Policy to protect informal workers. The policy provides unskilled workers in Durban with basic business skills training, legal advice, and access to health and education services. ${ }^{112}$

Developing effective collaborations between different levels of government will be critical to cities providing residents, including climate migrants, with adequate social and urban services. Given that national governments generally determine the allocation of funds to city governments, improved vertical collaboration can enable local government authorities to advocate for the scaling-up of resources for initiatives for migrant inclusion. Improved 
horizontal coordination between city governments in a larger metropolitan region can facilitate the improved delivery of urban services beyond city borders.

\section{POLICY RECOMMENDATIONS FOR CITIES:}

- Policies and laws to ensure that climate migrants have access to basic social services and infrastructure should be introduced.

- Municipal governments should introduce and enforce labor laws to ensure that people who work in the informal sector are protected from discrimination and exploitation.

- City governments should work to ensure that residents have equitable access to information. The flow of information will be critical in order for climate migrants to effectively participate in city-level decision-making processes.

- City governments should develop mechanisms to ensure the participation of city residents, including climate migrants, in city planning and decision-making processes.

- National governments should foster greater cooperation and communication between relevant national and city government agencies so that they can collaborate in addressing the challenges that climate migrants face in urban areas.

- City policies on migration must take into account gender-based vulnerability. Women migrants are among the most vulnerable as they are often poorer and marginalized in political decision-making processes that affect their livelihoods. Their participation in city planning processes is essential.

- City governments should introduce Strategic Development Frameworks which take a holistic look at all aspects of city planning. Such frameworks will examine climate change mitigation and adaptation, transport, housing, biodiversity, and green infrastructure in an integrated fashion.

- Ties between local community groups and city authorities should be strengthened in order to improve aid delivery and provide emergency shelter, water, and sanitation for people displaced by natural hazard events.

- Global aid agencies can work with climate migrant communities to assist them in establishing their own local councils to help them better participate in city-level decision-making processes.

- Local businesses should strengthen ties to migrant community groups with the goal of providing them with skills training and preparation for formal employment opportunities.

\section{Scaling Up Financial Resources}

Cities have considerable resource constraints and need financial resources to promote inclusion of climate migrants and provide urgently needed assistance to those people displaced by the impacts of climate change. Funding can come from municipal budgets, private investments, public-private-partnerships, regional and international development banks, international humanitarian and peacebuilding organizations, and UN agencies.

Among the UN agencies, the United Nations Human Settlements Programme (UN-Habitat) remains at the forefront when it comes to supporting initiatives to strengthen urban resilience and respond to humanitarian crises in urban settings. Since the 1990s, there has been a steady increase in humanitarian spending on the part of UN-Habitat, primarily through its programs to support climate-resilient cities and its Safer Cities Programme, which was launched 
streets can improve visibility at night and discourage criminal activity in neighborhoods. ${ }^{118}$ Also, ensuring that communities have access to basic waste, energy, and water services can reduce frustrations and feelings of exclusion that can escalate to violence. ${ }^{119}$

Public-Private Partnerships, where government services are provided in part through private-sector actors, can provide much-needed investment for urban development projects. These partnerships may contribute to improvements in the quality of the city's infrastructure while generating a wider range of employment opportunities for city residents, including climate migrants.

\section{Public-Private Partnership: Bus Rapid Transit System in Bogotà, Colombia}

Decades of armed conflict in Colombia displaced a large number of people from rural to urban areas. As a result, almost $75 \%$ of Colombians live in cities. Bogotá, the capital of Colombia, is a rapidly urbanizing city, with a growth rate of $2.5 \%$ annually. Population growth has created major challenges for the transportation sector, which is characterized by heavy congestion of roadways due to the high rate of use of private vehicles. In 1999 the mayor's office proposed the development of a public-private partnership to address congestion and provide transportation. The resulting partnership, named TransMilenio S.A. operates with split responsibilities where transportation infrastructure is supported by the government and actual operations and maintenance of

equipment is performed by private-sector partners. This partnership is considered to be a successful example of a public-private partnership to provide public transportation. ${ }^{120}$

Funding to ensure that climate migrants have access to basic infrastructure and social services can come from national governments, adaptation funding within the United Nations Framework Convention on Climate Change (UNFCCC), and aid from international development organizations. As international funding for climate adaptation initiatives increases, a portion of this funding can be channeled towards city programs and grassroots, migrant-led initiatives. At the UN Climate Conference in Cancun (COP 16), which took place in November 2010, governments agreed that climate migrants are qualified for assistance under a number of funding channels within the UNFCCC, namely the Green Climate Fund and the Least Developed Countries Fund. The Green Climate Fund aims to raise \$100 billion by the year 2020, ${ }^{121}$ with the majority of this funding coming from governments of developed countries. Local governments can access financial resources from these funding strategies by submitting project proposals to be part of the UNFCCC's National Adaptation Programmes of Action, Intended Nationally Determined Contributions, and National Adaptation Plans.

\section{POLICY RECOMMENDATIONS FOR CITIES:}

- Private sector development can lead to job creation. Ensuring that residents have access to employment opportunities can reduce levels of crime and violence in urban areas. Job creation should be targeted particularly to young people to ensure that they do not engage in criminal behaviors.

- Funding for city-wide programs for violence prevention should be scaled up. Funding should be targeted towards participatory programs in which city residents are engaged in assessing and measuring security issues at the neighborhood and city levels.

- Funding for city-wide programs which address the challenges that climate migrants face in urban areas should be scaled up. 


\section{Policy Recommendations for Cities, continued}

- Ties with private companies can be strengthened so they can invest in upgrading urban infrastructure. In addition, it is crucial to have private sector engagement in emergency preparedness and humanitarian responses in urban contexts.

- Ties with regional and international development banks, such as the World Bank, the African Development Bank, and the Asian Development Bank, should be strengthened. International and regional banks can channel investments towards upgrading basic infrastructure and improved service delivery.

- Funding should be scaled up for capacity-building programs aimed at strengthening urban governance, specifically programs for developing effective public leadership, strengthened city councils, and inclusive participation in city planning and decision-making. This funding can come from international donor agencies such as the International Committee of the Red Cross, the UK's Department for International Development (DFID), and USAID.

- Humanitarian aid should focus on building cities that are resilient to the challenges associated with climate-induced migration in a way that is holistic and integrated. This approach is likely to be more effective than individual programs aimed at tackling infrastructure and social programs.

- Public-private partnerships can facilitate much-needed support-financial and technical-for infrastructure projects while providing employment opportunities for city dwellers including climate migrants.

- International funding schemes within the UNFCCC, such as the Green Climate Fund and the Least Developed Countries Fund, can be a means for providing funding for initiatives to improve the livelihoods and overall well-being of climate migrants.

- Financial resources should be facilitated so that city governments can collect data and identify the challenges faced by climate migrants in their territories.

- Climate migrants should be ensured a voice in decisions around international, national, and local adaptation funding.

- Scaled-up funding should be made available for humanitarian assistance for people displaced by natural hazard events, particularly for waste, water, and health services.

- Stronger inter-linkages between humanitarian, peacekeeping, and climate change-related interventions should be reflected in funding responses.

- It is essential to recognize the important role of private sector engagement in emergency preparedness and humanitarian responses in urban contexts.

- Funding should be channeled towards infrastructure projects that can deliver social benefits such as inclusion, health and well-being, biodiversity, and climate change mitigation and adaptation.

- Global aid should be channeled towards research to develop infrastructure projects that are smaller in scale and can provide interim solutions between larger infrastructure projects. These include, for example, decentralized energy solutions and potable water delivery projects.

- Investments in the urban realm should be part and parcel of all development projects.

- Global aid should be channeled towards developing project management skills among climate migrant communities. Specifically, local communities should learn how to manage local-level development projects. In this way, many development projects could be delivered at a lower cost while giving climate migrants a sense of ownership. 


\section{Partnerships to Complement Local Action}

Given the limited institutional capacities of city governments in low- and middle-income countries to effectively address pressing urbanization, migration, security, and humanitarian challenges, external partnerships can provide much-needed support to cities.

City governments will need to build partnerships with humanitarian organizations in order to effectively deliver humanitarian assistance to environmentally displaced people. The main international aid organizations providing humanitarian assistance in urban contexts

Delivery of humanitarian assistance is more effective when strategies for multi-stakeholder partnerships are developed early. include the International Rescue Committee, the International Federation of the Red Cross, CARE International, and Oxfam International. Research shows that the delivery of humanitarian assistance is more effective when strategies for multi-stakeholder partnerships are developed early, before any emergency or acute crisis requiring an immediate response. ${ }^{122}$ The international community is recognizing the crucial role of city governments as key actors in the delivery of effective humanitarian aid, primarily because city government authorities are in close proximity to their local communities. Coordination mechanisms should be put in place to ensure that city government authorities and local community groups collaborate with one another for the effective delivery of aid at the local level.

There is also a need for city governments to build bridges with think tanks and their global research programs at the international level. Such partnerships can fill in gaps in knowledge on the dynamics of urban trends, city governance, climate migration, and security. Enhanced knowledge can help city leaders design better policies and programs addressing the climate-migration-security nexus. The main think tanks working on issues of urban fragility and security include the London School of Economics' initiative on Cities and Fragile States, the Fragile Cities program at the International Peace Institute, and the Safe and Inclusive Cities program at the International Development Research Centre of DFID.

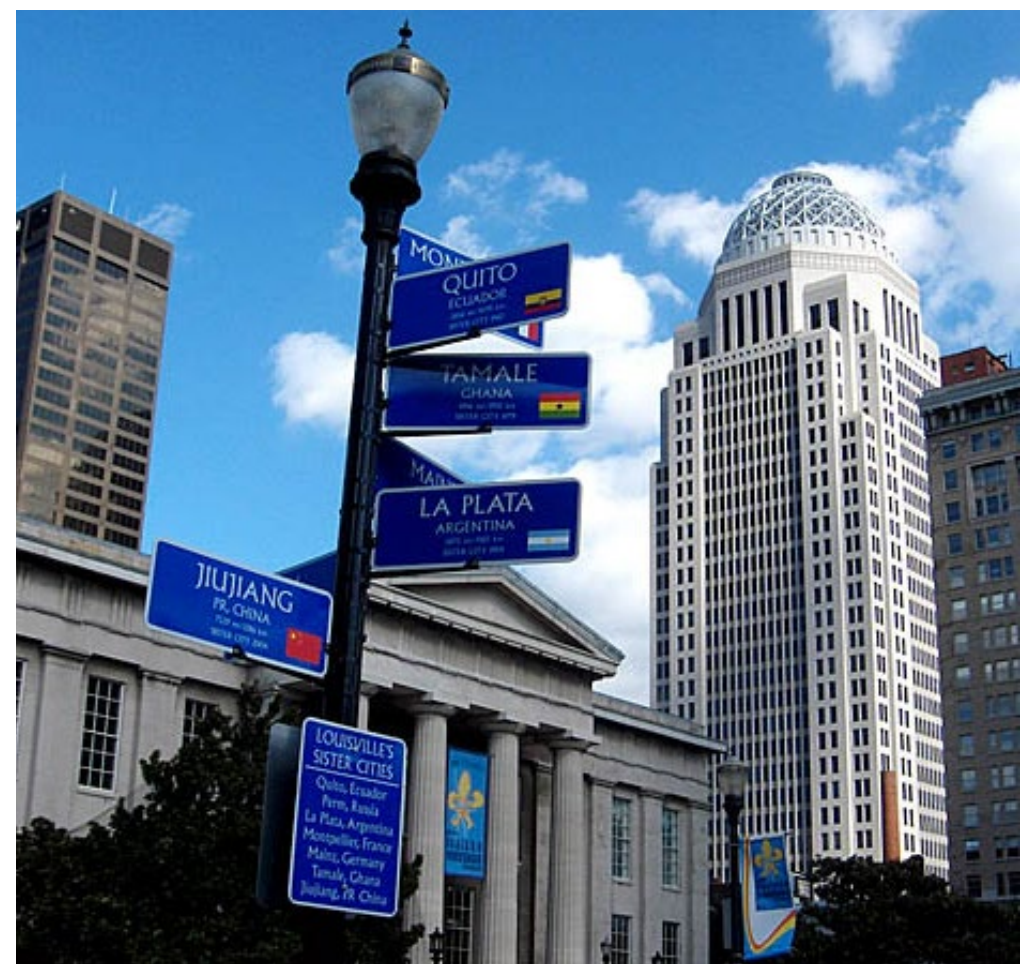

Louisville sister cities. Photo: Derek Cashman
Sister-city partnerships between cities in the developing and developed world can lead to the sharing of ideas on good governance practices and ideas for innovations in urban infrastructure. In addition, such partnerships can facilitate much-needed funding for migrant inclusion initiatives in resourceconstrained cities. Nonprofit organizations such as Sister Cities International can strengthen the capacities of underresourced cities, primarily through institutional partnerships, knowledgesharing, and grant programs.

Agreements between city governments within the same country can lead to the exchange of information and skills/ knowledge-sharing between city leaders 


\section{Beijing-Copenhagen Sister-City Partnership for Sustainable Urban Development}

On June 26, 2012, Beijing and Copenhagen signed a mutual "sister cities" agreement to improve collaboration between the two cities, particularly in the areas of energy efficiency, renewable energy, water management, and flood management. "The city of Beijing says it wants to focus on sustainable solutions, the clean technology sector, social welfare and livability, and how to be a growing city and still have a focus on citizens' quality of life. I think we have a lot to share with each other to develop both cities." ${ }^{123}$

The two cities plan on the following initiatives:

- Technical collaboration on urban energy-efficiency systems, waste systems, and wastewater management.

- A private-public partnership to stimulate job creation in the green jobs sector.

- Working with local businesses and universities in both cities to develop green technologies.

and their staff members. Programs to address climate migration and security challenges should recognize that cities relate to other cities within the same country and can learn from one another to be more effective in addressing local-level challenges. These arrangements can also promote greater cooperation among marginalized communities, such as climate migrants, in different municipal jurisdictions so they can form coalitions with one another in order to better advocate for their rights at the local and national levels.

Avenues for city leaders to share ideas and resources aiming to strengthen the resilience of climate migrants include the World Mayors Council on Climate Change, ICLEI-Local Governments for Sustainability, United Cities and Local Governments, the C40 Cities Climate Leadership Group, and the Making Cities Resilient campaign of the United Nations Office for Disaster Risk Reduction. ICLEI-Local Governments for Sustainability is a network of local governments which includes more than 1,500 cities and towns from around the world. Since 2010, ICLEI has hosted the annual Resilient Cities congress, also known as the Global Forum on Urban Resilience and Adaptation, which provides a platform for cities to share expertise and ideas with one another. The C40 Cities Climate Leadership Group includes more than 80 cities focused on implementing measures to improve urban adaptive capacity and supports its members through research and knowledge-sharing. Their recent policy report, "Potential for Climate Action," identified approximately 27,000 actions that cities have yet to implement to tackle climate change with recommendations on ways that cities can implement those actions. ${ }^{124}$

Building ties between local governments and the UN Safer Cities Programme can lead to safer, more inclusive urban areas in low- and middle-income countries. The Safer Cities Programme ${ }^{125}$ connects international experts to city leaders to help these leaders craft local action plans focused on "bottom-up" approaches to violence prevention. 


\section{POLICY RECOMMENDATIONS FOR CITIES:}

- The UN General Assembly can call a special session on climate change, migration, conflict, and cities to foster dialogue among city officials and international policymakers. The session could generate solutions to the security challenges associated with climate-induced migration to cities.

- Partnerships between local government authorities and research programs can generate much-needed data and information regarding the links between cities, climate-induced migration, and conflict. Local government authorities should strengthen ties with global research programs. City governments should strengthen ties between city government decision-makers and global research programs such as the initiative on Cities and Fragile States from the London School of Economics, the Fragile Cities program at the International Peace Institute, and the Safe and Inclusive Cities program of the International Development Research Centre of DFID.

- Sister-city partnerships can facilitate the sharing of ideas, technical expertise, and resources, with the aim of strengthening resilience in fragile cities.

- Ties should be strengthened between city officials and international policymakers on climate change, migration, and security policy.

- The active engagement of city leaders in multilateral forums on international climate change policy, such as the UN Framework Convention on Climate Change, should be encouraged.

- City leaders can actively engage in international coalitions on climate change and adaptation, such as the World Mayors Council on Climate Change, ICLEI-Local Governments for Sustainability, and the C40 Cities Climate Leadership Group. These networks can facilitate technical knowledge and even financial resources to build the adaptive capacity of local urban governments in low- and middleincome countries.

- City governments should forge partnerships with the UN's Safer Cities Programme, which encourages initiatives calling for more bottom-up approaches to violence prevention.

- Agreements should be forged between city governments within the same country. These arrangements can promote greater cooperation among climate migrants so they can form coalitions with one another and advocate for their rights at the local and national levels.

- Partnerships between city governments and international peace, security, and humanitarian organizations can be strengthened.

- City governments should strengthen ties with the United Nations Office for the Coordination of Humanitarian Affairs, the lead agency for bringing together humanitarian actors and emergency responses.

- Greater coordination and stronger ties among city governments, national governments, and international humanitarian organizations should be ensured.

- Cities should strengthen ties with the Global Alliance for Urban Crises, which brings together city leaders, urban professionals, the development community, and the private sector to deal with response to humanitarian challenges in urban areas. 


\section{REFERENCES}

1 Timothy Weisberg, "Typhoon Haiyan by the Numbers," NBC New York, November 13, 2013, http://www.nbcnewyork.com/news/ national-international/By-the-Numbers-Typhoon-Haiyan-Yolanda-231580591.html.

2 Ibid.

3 International Displacement Monitoring Centre (IDMC), “Global Estimates 2014: People Displaced by Disasters," September 2014, http:www.internal-displacement.org/assests/publications.

4 International Displacement Monitoring Centre (IDMC), “Global Estimates 2014: People Displaced by Disasters,” September 2014, http:www.internal-displacement.org/assests/publications.

5 J.T. Houghton, G.J. Jenkins and J.J. Ephraums (eds.), "Climate Change: The IPCC Scientific Assessment," Report Prepared for the Intergovernmental Panel on Climate Change by Working Group I (Cambridge, UK: Cambridge University Press, 1990), https://www. ipcc.ch/publications and data/publications ipcc first assessment $1990 \mathrm{wg} 1 . \mathrm{shtml}$.

6 Michael Werz and Laura Conley, "Climate Change, Migration, and Conflict: Addressing the Complex Crisis Scenarios in the $21^{\text {st }}$ Century," Center for American Progress, January 3, 2012, https://www.americanprogress.org/issues/security/ reports/2012/01/03/10857/climate-change-migration-and-conflict/.

7 The International Rescue Committee, "Humanitarian Action in an Urban World," August 2016, https://www.rescue-uk.org/sites/ default/files/document/917/urbanprinciples6blackweb.pdf.

8 Muggah, Robert “Fragile Cities Rising,” IPI Global Observatory, 10 July 2013, http://theglobalobservatory.org/2013/07/fragilecities-rising/

9 Andrew Morton, Philippe Boncour and Frank Laczko, "Human Security Policy Challenges," Climate Change and Displacement: Forced Migration Review 31, October 2008, http://www.fmreview.org/sites/fmr/files/FMRdownloads/en/FMRpdfs/FMR31/05-07. pdf.; The Government Office for Science, "Migration and Global Environmental Change: Future Challenges and Opportunities" (London, UK: Government Office for Science, 2011), https://www.gov.uk/government/uploads/system/uploads/attachment data/ file/288793/11-1117-migration-global-environmental-change-scenarios.pdf.

10 Coral Davenport, "Rising Seas," The New York Times, March 27, 2014, https://www.nytimes.com/interactive/2014/03/27/world/ climate-rising-seas.html? $r=0$.

11 Houghton, Jenkins and Ephraums, "Climate Change: The IPCC Scientific Assessment."

12 Liz Heimann, "Climate Change and Natural Disasters Displace Millions, Affect Migration Flows," Migration Policy Institute, December 10, 2015, http://www.migrationpolicy.org/article/top-10-2015-\%E2\%80\%93-issue-7-climate-change-and-naturaldisasters-displace-millions-affect.

13 IDMC, "Global Estimates 2014: People Displaced by Disasters."

14 Oli Brown, “Migration and Climate Change," International Organization for Migration Research Series 31 (Geneva: IOM, 2008), https://www.iom.cz/files/Migration and Climate_Change__IOM Migration Research Series No 31.pdf.

15 Brookings Institute, "Climate Change and Internal Displacement."

16 "The Nansen Conference: Climate Change and Displacement in the $21^{\text {st }}$ Century" (materials presented at The Nansen Conference, Oslo, Norway, June 5-7, 2011), available at http://www.refworld.org/docid/521485ef4.html.

17 International Organization for Migration, “Migrants and Cities: New Partnerships to Manage Mobility," IOM World Migration Report 2015 (Geneva: IOM, 2015), https://publications.iom.int/books/world-migration-report-2015-migrants-and-cities-new-partnershipsmanage-mobility.

18 Poppy McPherson, "Dhaka: The City Where Climate Refugees are a Reality," The Guardian, December 1, 2015, https://www. theguardian.com/cities/2015/dec/01/dhaka-city-climate-refugees-reality.

19 Fahad Saeed, Kashif Majeed Salik and Sadia Ishfaq, "Climate Change and Heat-Waves: Rural-to-Urban Migration in Pakistan, a Looming Crisis," Sustainable Development Policy Institute Policy Brief 47, 2015, https://sdpi.org/publications/files/Climate-Changeand-Heat-Waves-Rural-to-Urban-Migration-in-Pakistan-A-silent-Looming-Crisis.pdf.

20 Ibid.

21 IDMC, "Global Estimates 2014: People Displaced by Disasters."

22 United Nations Population Fund, “Urbanization," accessed March 6, 2017, http://www.unfpa.org/urbanization.

23 World Health Organization, "Urbanization and Health," Bulletin of the World Health Organization 88(4), April 2010, http://www. who.int/bulletin/volumes/88/4/10-010410/en/.

24 "Percentage of Global Population Living in Cities, by Continent," The Guardian DataBlog, accessed June 7, 2016, http://www. theguardian.com/news/datablog/2009/aug/18/percentage-population-living-cities.

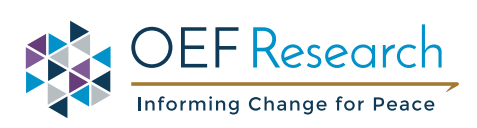


25 United Nations Department of Economic and Social Affairs, "World Urbanization Prospects: The 2014 Revision," ST/ESA/SER.A/352 (New York: United Nations, 2014), https://esa.un.org/unpd/wup/Publications/Files/WUP2014-Highlights.pdf.

26 UN-Habitat, “World Cities Report 2016: Urbanization and Development, Emerging Futures," United Nations Human Settlements Programme, 2016.

27 Peter Farrar, “China's New Generation of Urban Migrants," The Diplomat, June 29, 2016, http://thediplomat.com/2016/06/chinasnew-generation-of-urban-migrants/.

28 Ibid.

29 Kevin Savage and Robert Muggah, "Urban Violence and Humanitarian Action," Journal of Humanitarian Assistance, January 19, 2012, available at https://sites.tufts.edu/jha/archives/1524.

30 Ibid.

31 Ibid.

32 Savage and Muggah, "Urban Violence and Humanitarian Action."

33 Ibid.

34 Robert Muggah, “How Fragile are Our Cities?" The World Economic Forum, February 9, 2016, https://www.weforum.org/ agenda/2016/02/how-fragile-are-our-cities/.

35 UN-Habitat, "World Cities Report 2016."

36 World Health Organization (WHO), "Meeting the MDG Drinking Water and Sanitation Target: The Urban and Rural Challenge of the Decade" (Geneva: WHO and UNICEF, 2004), http://www.who.int/water_sanitation health/monitoring/impfinal.pdf.

37 Sudeshna Ghosh Banerjee and Elvira Morella, "Africa's Water and Sanitation Infrastructure: Access, Affordability, and Alternatives," The World Bank, March 9, 2011, DOI: http://dx.doi.org/10.1596/978-0-8213-8457-2.

38 Sheridan Bartlett and David Satterthwaite, Cities on a Finite Planet: Towards Transformative Responses to Climate Change (New York, NY: Routledge, 2016).

39 United Nations, "Water and Cities," UNESDA and UN Fact Sheet, http://www.un.org/waterforlifedecade/pdf/facts and figures short eng.pdf.

40 Bartlett and Satterthwaite, Cities on a Finite Planet.

41 Annette Pruss-Ustun, Robert Bos, Fiona Gore and Jamie Bartram, Safer Water, Better Health: Costs, Benefits, and Sustainability of Interventions to Protect and Promote Health (Geneva: World Health Organization, 2008).

42 Venkata Ramana Putti, "Energy Access for Poor in Urban and Peri-Urban Areas: An Emerging Challenge," The World Bank Energy Sector Management Assistance Program, November 15, 2011, http://siteresources.worldbank.org/EXTAFRREGTOPENERGY/ Resources/717305-1327690230600/8397692-1327691245128/Urban and Peri Urban Challenges_AEI Workshop.pdf.

43 Getamesay Bekele, "Energy Poverty in Addis Ababa City, Ethiopia," Journal of Economics and Sustainable Development 6(3), 2015.

44 United Nations General Assembly, "Policy Paper 4: Urban Governance, Capacity, and Institutional Development," UN Policy Paper A/CONF.226/PC.3/17, February 29, 2016, http://www.un.org/ga/search/view doc.asp?symbol=A/CONF.226/PC.3/17.

45 Koos Neefjes, “Migration, Resettlement and Climate Change in Viet Nam" (Hanoi: United Nations Development Programme, 2014), http://www.undp.org/content/dam/vietnam/docs/Publications/Migration\%20\&\%20Climate\%20change\%20-\%20Eng.pdf.

46 IOM, "Migrants and Cities: New Partnerships to Manage Mobility."

47 Association of Chartered Certified Accountants (ACCA), "Improving Public Sector Financial Management in Developing Countries and Emerging Economies," 2010, http://www.accaglobal.com/content/dam/acca/global/PDF-technical/public-sector/tech-afbipsfm.pdf.

48 United Cities and Local Governments, "Local Government Finance: The Challenges of the $21^{\text {st }}$ Century-Second Global Report on Decentralization and Local Democracy," 2010, http://www.cities-localgovernments.org/gold/Upload/gold report 2/2010\%20 EXECUTIVE\%20SUMMARY\%20baixa.pdf.

49 Ede ljjasz-Vasquez, "To Grow Sustainably, Cities First Need to Get Their Finances Right," World Bank Sustainable Cities Blog Series, February 25, 2016, http://blogs.worldbank.org/sustainablecities/grow-sustainably-cities-first-need-get-their-finances-right.

50 United Cities and Local Governments, "Local Government Finance."

51 Ibid.

52 ACCA, "Improving Public Sector Financial Management in Developing Countries and Emerging Economies."

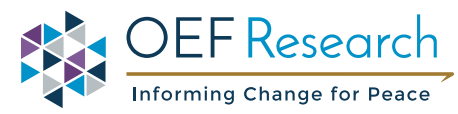


53 UN-Habitat, "Local Authorities and Municipal Finance," UN document GRHS/05/F8, 2010, https://unhabitat.org/wp-content/ uploads/2005/11/GRHS05F8.pdf.

54 Jan Brueckner and Somik Lall, "Cities in Developing Countries: Fueled by Rural-Urban Migration, Lacking in Tenure Security, and Short of Affordable Housing," chapter in The Handbook of Regional and Urban Economics Volume 5, eds. G. Duranton, J.V. Henderson and W. Strange, July 2014, http://real.wharton.upenn.edu/ duranton/Duranton_Papers/Handbook/Cities in developing_countries fueled by rural urban migration lacking_in tenure security and_short_of_affordable housing.pdf.

55 Ibid.

56 International Organization for Migration, Migration, Development, and Poverty Reduction in Asia (Geneva: IOM, 2005).

57 IOM, "Migrants and Cities: New Partnerships to Manage Mobility."

58 Priya Deshingkhar, Rajiv Khandelwal and John Farrington, "Support for Migrant Workers: The Missing Link in India's Development," Overseas Development Institute Briefing Paper in ODI Natural Resource Perspectives, September 2008, https://www.odi.org/sites/ odi.org.uk/files/odi-assets/publications-opinion-files/3343.pdf.

59 International Organization of Migration, Migration, Development, and Poverty Reduction in Asia.

60 Deshingkhar, Khandelwal and Farrington, "Support for Migrant Workers."

61 Caroline Schultz, "Migration, Health and Urbanization: Interrelated Challenges," Background Paper of the International Organization for Migration's World Migration Report 2015, December 2014, https://www.iom.int/sites/default/files/our work/ICP/ MPR/WMR-2015-Background-Paper-CSchultz.pdf.

62 Kate Meagher, "Unlocking the Informal Economy: A Literature Review on Linkages Between Formal and Informal Economies in Developing Countries," Women in Informal Employment Globalizing and Organizing (WIEGO) Working Paper, WIEGO Publication Series 27, April 2013, http://www.wiego.org/sites/default/files/publications/files/Meagher-Informal-Economy-Lit-Review-WIEGOWP27.pdf.

63 Abdullah Al Zayeed, "Informal Sector and its Impact on Dhaka," bdnews24.com, April 11, 2016, http://opinion. bdnews24.com/2016/04/11/informal-sector-and-its-impact-on-dhaka/.

64 Neefjes, "Migration, Resettlement, and Climate Change in Viet Nam."

65 Martha Chen, "Informality and Social Protection: Theories and Realities," Institute for Development Studies Bulletin 39(2) pp.18-27, 2008, DOI: 10.1111/j.1759-5436.2008.tb00441.x.

66 SEWA "Parliament passes Unorganised Workers Social Security Act 2008 and SEWA's Resolution" We, The Self-Employed: SEWA's Electronic Newsletter, No. 17, August-December 2008, http://www.sewa.org/Seventeenth_Issue.asp

67 International Labour Organization, World Employment Report 2004-2005: Employment, Productivity, and Poverty Reduction (Geneva: ILO, December 6, 2004), http://www.ilo.org/public/libdoc/ilo/P/09465/09465\%282004-2005\%29272.pdf.

68 John Burton, Violence Experienced: The Source of Violence and Crime and their Prevention (New York, NY: Manchester University Press, 1997).

69 Laurie Nathan, “Crisis Resolution and Conflict Management in Africa," Center for Conflict Resolution, 2003.

70 Richard Sandbrook, The Politics of Basics Needs (Toronto: University of Toronto Press, 1982).

71 World Bank, "Stop Conflict, Reduce Fragility, and End Poverty: Doing Things Differently in Fragile and Conflict-Affected Situations," 2015.

72 Jonathan Goodhand, "Violent Conflict, Poverty, and Chronic Poverty," Chronic Poverty Research Centre Working Paper 6, May 2001, http://www.chronicpoverty.org/uploads/publication files/WP06 Goodhand.pdf.

73 Robert Muggah, "More Slums Equals More Violence: Reviewing Armed Violence and Urbanization in Africa," United Nations Development Programme, October 2007, http://www.genevadeclaration.org/fileadmin/docs/regional-publications/ArmedViolence-and-Urbanization-in-Africa.pdf.

74 Ibid.

75 Mayra Buvinic and Andrew Morrison, "Causes of Violence," Inter-American Development Bank Sustainable Development Department Technical Note 3 (Washington, D.C.: IADB, 1999).

76 Edward Glaeser and Bruce Sacerdote, "Why is There More Crime in Cities?" Journal of Political Economy 107(S6), December 1999.

77 UN-Habitat, "Crime in the City," UN-Habitat Case Study, October 1, 2007, http://unhabitat.org/wp-content/ uploads/2008/07/5204 47267 Bk-8.pdf.

78 Ashley Wilson and Joshua Ogure, "Brutal Crackdown on Election Reformers in Kenya's Biggest Slum," National Geographic Explorer, June 2016, http://voices.nationalgeographic.com/2016/06/02/brutal-crackdown-on-election-reformers-in-kenyas-biggest-slum/.

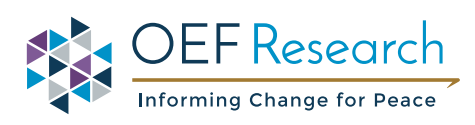


79 Ibid.

80 Barbora Holicka, "The Connection Between Poverty and Gender-Based Violence in Kibera: Lessons and Opportunities," GBV Uncovered, June 26, 2015, http://www.gbvuncovered.com/blog/gbv-kibera-lessons-and-opportunities.

81 UN HABITAT, "Safer Cities Initiative", http://mirror.unhabitat.org/content.asp?cid=7337\&catid=206\&typeid=13

82 Peter Gizewski and Thomas Homer-Dixon, “Urban Growth and Violence: Will the Future Resemble the Past?” http://www. homerdixon.com/projects/eps/urban/urban2.htm.

83 The World Bank, "Violence in the City: Understanding and Supporting Community Responses to Urban Violence," The World Bank Social Development Department Conflict, Crime, and Violence Team document, April 2011.

84 Ibid.

85 Sherrian Gray, "Trends in Urban Crime and Violence in Kingston" (case study prepared for Enhancing Urban Safety and Security: Global Report on Human Settlements 2007), http://unhabitat.org/wp-content/uploads/2008/07/GRHS.2007.CaseStudy.Crime . Kingston.pdf.

86 ActionAid International, "Women Face Constant Fear of Violence in Public Spaces," February 21, 2013, https://www.actionaid.org. uk/latest-news/women-face-constant-fear-of-violence-in-public-spaces-says-actionaid.

87 Annie Kelly, "Poor Urban Services Found to Increase Risk of Violence Against Women," The Guardian, February 21, 2013, https:// www.theguardian.com/global-development/2013/feb/21/urban-services-violence-against-women.

88 Ibid.

89 Michael Renner, "The Anatomy of Resource Wars," Worldwatch Institute Worldwatch Paper 162, October 2002.

90 Michael Ross, "Natural Resources and Civil War: An Overview," World Bank Research Observer, August 15, 2003.

91 Thomas Homer-Dixon, "Environment, Scarcity, and Violence: Evidence from Cases," International Security 19(1), 1994.

92 Jared Diamond, Collapse: How Societies Choose to Fail or Succeed (New York, NY: Viking Press, 2005).

93 The Intergovernmental Panel on Climate Change, Climate Change 2007: Synthesis Report, contribution of Working Groups I, II and III to the Fourth Assessment Report of the Intergovernmental Panel on Climate Change (Geneva: IPCC, 2007), http://www.ipcc.ch/ publications_and_data/publications_ipcc_fourth_assessment_report_synthesi s_report.htm.

94 Leif Ohlsson, The Risk of Livelihood Conflicts and the Nature of Policy Measures Required (Washington, D.C.: Carolina Academic Press, 2003).

95 Jon Barnett and W. Neil Adger, "Climate Change, Human Security and Violent Conflict," Political Geography 26(6): 639-655, 2007.

96 Thomas Homer-Dixon, Environment, Scarcity and Violence (Princeton, NJ: Princeton University Press, 1999).

97 Halvard Buhaug, Nils Petter Gleditsch and Ole Magnus Theisen, "Implications of Climate Change for Armed Conflict" (paper presented at the World Bank workshop on Social Dimensions of Climate Change, the World Bank, Washington D.C., March 2008), available at http://siteresources.worldbank.org/INTRANETSOCIALDEVELOPMENT/Resources/SDCCWorkingPaper_Conflict.pdf.

98 Rafael Reuveny, “Climate Change-Induced Migration and Violent Conflict," Political Geography 26(6), August 2007.

99 Werz and Conley, "Climate Change, Migration, and Conflict."

100 Reuveny, "Climate Change-Induced Migration and Violent Conflict."

101 Nils Petter Gleditsch, "Regional Conflict and Climate Change" (paper prepared for the workshop on Research on Climate Change Impacts and Associated Economic Damages, Washington D.C., January 27-28, 2011).

102 Buhaug, Gleditsch and Theisen, "Implications of Climate Change for Armed Conflict."

103 Werz and Conley, "Climate Change, Migration, and Conflict."

104 Clionadh Raleigh, Lisa Jordan and Idean Salehyan, "Assessing the Impact of Climate Change on Migration and Conflict" (paper presented at the World Bank workshop on Social Dimensions of Climate Change, the World Bank, Washington D.C., March 2008), http://siteresources.worldbank.org/EXTSOCIALDEVELOPMENT/Resources/SDCCWorkingPaper MigrationandConflict.pdf.

105 David Cortright, Conor Seyle and Kristen Wall, Governance for Peace: How Inclusive, Participatory and Accountable Institutions Promote Peace and Prosperity (Cambridge, UK: Cambridge University Press, forthcoming).

106 Christian Davenport, State Repression and the Domestic Democratic Peace (Cambridge, UK: Cambridge University Press, 2007).

107 Donald L. Horowitz, Ethnic Groups in Conflict (Berkeley: Univ. of California Press, 1985); Arend Lijphart, Thinking About Democracy: Power Sharing and Majority Rule in Theory and Practice (New York, NY: Routledge, 2008); Andrew Reynolds, Designing Democracy in a Dangerous World (Oxford, UK: Oxford University Press, 2011).

108 IOM, "Migrants and Cities: New Partnerships to Manage Mobility."

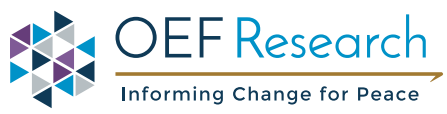


109 Terry Parker, "Improving Institutional and Service Delivery Capacity in Conflict Affected Areas: The Experience of Honiara City Council, Solomon Islands," Commonwealth Journal of Local Governance 6, July 2010.

110 Women in Informal Employment Globalizing and Organizing, "Street Vendors in Lima, Peru," WIEGO Impact Stories, http://www. wiegoinbrief.org/lima-peru/.

111 lbid.

112 Susanne David, Oliver Ulrich, Serge Zelezeck and Nachi Majoe (eds.) "Managing Informality: Local Government Practices and Approaches Towards the Informal Economy: Learning Examples from Five African Countries," Initiative of the South African Local Economic Development Network and the Local Economic Development Network of Africa, 2012, http://www.enterprisedevelopment.org/wp-content/uploads/managing_informality local_governments_practices towards the informal_economy.pdf.

113 International Peace Institute, “Fragile States and Fragile Cities," IPI Discussion Paper, November 2015.

114 UN-Habitat, "Safer Cities Programme," http://unhabitat.org/urban-initiatives/initiatives-programmes/safer-cities/.

115 African Development Bank Group, http://www.afdb.org/en/.

116 Ibid.

117 Steven Zyck and Randolph Kent, "Humanitarian Crises, Emergency Preparedness, and Response: The Role of Business and the Private Sector, Final Report" Overseas Development Institute, July 2014, https://www.odi.org/sites/odi.org.uk/files/odi-assets/ publications-opinion-files/9078.pdf.

118 World Bank, "Violence in the City: Understanding and Supporting Responses to Violence," World Bank Working Paper, April 2011.

119 lbid.

120 United Nations Development Programme. "Bus Rapid Transit Project, Bogotá, Colombia” United Nations Development Programme. 2008. Sharing Innovative Experiences, Volume 15: Examples of Successful Public-Private Partnerships.

121 Green Climate Fund, http://www.greenclimate.fund/home.

122 Francois Grunewald, Beatrice Boyer, Domitille Kauffmann and Julie Patinet, "Humanitarian Aid in Urban Settings: Current Practice, Future Challenges," Groupe URD Report, December 2011, available at https://www.scribd.com/document/179808610/ Humanitarian-aid-in-urban-settings-current-practice-future-challenges.

123 David Bartram and Ji Xiang "Sisterly relations at a stretch" China Daily Europe, March 15 2013. http://europe.chinadaily.com.cn/ epaper/2013-03/15/content_16310166.htm

124 C40 Cities, "Potential for Climate Action," Report of the C40 Cities Climate Leadership Group and Arup, December 2015, https:// app.box.com/s/ry5d72tpidxc8x9fjljedlw4kyq692bi.

125 UN-Habitat, "Safer Cities Programme," https://unhabitat.org/urban-initiatives/initiatives-programmes/safer-cities/.

126 Ken Menkhaus, "If Mayors Ruled Somalia: Beyond the State-Building Impasse," Nordic Africa Institute Policy Note 2, 2014, http:// nai.diva-portal.org/smash/get/diva2:714676/FULLTEXT01.pdf. 


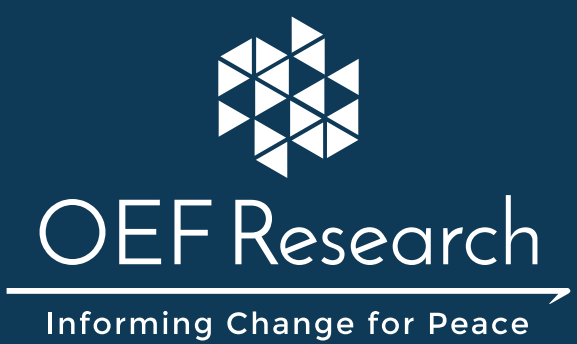

OEF Research is a program of

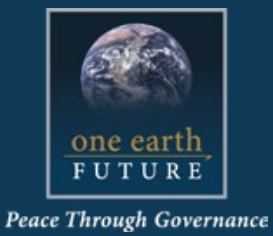

www. oneearthfuture.org 